\title{
EFISIENSI PENGGUNAAN EKUITAS PADA LEMBAGA PERKREDITAN DESA (LPD) DESA PAKRAMAN LALANGLINGGAH KABUPATEN TABANAN PERIODE 2013-2015
}

\author{
Ni Made Yuda Dwi Aristini \\ Jurusan Akuntansi Program Diploma III \\ Universitas Pendidikan Ganesha, Singaraja \\ e-mail : $\underline{d}$ aristini@yahoo.com
}

\begin{abstract}
Abstrak
Penelitian ini bertujuan untuk mengetahui efisiensi penggunaan ekuitas pada LPD Desa Pakraman Lalanglinggah Kabupaten Tabanan Periode 2013-2015.Subyek dalam penelitian adalah Lembaga Perkreditan Desa (LPD) Desa Pakraman Lalanglinggah Kabupaten Tabanan.Obyek penelitian ini adalah mengenai efisiensi penggunaan ekuitas tahun 2013-2015. Metode pengumpulan data yang digunakan adalah metode dokumentasi dengan sumber data yaitu data sekunder.Teknik analisis data yang digunakan adalah teknik analisis deskriptif kuantitatif.

Hasil penelitian menunjukkan jika dilihat dengan rentabilitas ekonomis, penggunaanekuitas kerja dari tahun 2013-2015 terjadi fluktuatif. Pada tahun 2013 penggunaan ekuitas kerja kurang efisien, tahun 2014 penggunaan ekuitas kerja sangat efisien, dan tahun 2015 penggunaan ekuitas kerja kurang efisien. Kemudian bila dilihat dari rentabilitas modal sendiri penggunaan ekuitas kerja tahun 2013 tergolong kurang efisien dan tahun 2014-2015 penggunaan ekuitas kerja tergolong sangat efisien.
\end{abstract}

Kata-kata kunci : efisiensi, ekuitas, rentabilitas, LPD

\section{Abstract}

This study aims to determine efficiency the usage of equity in the Ipd desa pakraman lalanglinggah tabanan regency period 2013-2015. Subjects in the study is the village credit institutions (Ipd) desa pakraman lalanglinggah tabanan regency. Object of this research is efficiency the usage of equity in 2013-2015. Methods of data collection using documentation method with sources of data is secondary data.data analysis using quantitative descriptive.

The results showed when viewed with the economic rentability, in 2013-2015 work equity usage occurred fluctuated. In 2013 the use of workequity is less efficient, in 2014 work equity usage highly efficient, and in 2015 the use of work equity is less efficient. Then when viewed from rentability of own capital the use of work equity in 2013 classified as less efficient and the years 2014 to 2015 the use of work equity is very efficient.

Keywords :efficiency, equity, rentability, Ipd 


\section{Pendahuluan}

Bali sangat terkenal diseluruh Indonesia bahkan diseluruh dunia sebagai tujuan wisata dengan seni dan kebudayaannya yang unik, salah satu keunikan di Bali adalah eksistensi dari desa pakraman atau desa adat.Lingkup kegiatan desa pakraman di Bali tidak terbatas pada peran-peran sosial budaya dan keagamaan saja, melainkan juga ekonomi dan pelayanan umum yang biasanya berasal dari pemerintah.

Melihat beratnya beban yang dipikul oleh desa pakraman, tentunya terbesit seberapa besar dana yang harus dikeluarkan oleh desa pakraman, tetapi ironisnya pembiayaan desa pakraman berada diluar kebijakan pembiayaan pemerintah. Karena itu desa pakraman dituntut untuk memiliki tata kelola perekonomian mandiri.Hal ini mendorong pemerintah untuk membentuk suatu lembaga yang bersifat khusus yang diharapkan dapat menunjang kelancaran pembangunan di desa Pakraman.Sehingga pada tahun 1984 pemerintah Bali mencetuskan pendirian Lembaga Pengkreditan Desa diseluruh desa pakraman di Bali.

Maksud dan tujuan berdirinya Lembaga Perkreditan Desa (LPD) adalah untuk menjaga pembangunan didesa adat, memeratakan perekonomian di desa adat serta perluasan kesempatan kerja bagi krama desa.Kegitan pokok Lembaga Perkreditan Desa (LPD) adalah melayani jasa simpan pinjam bagi masyarakat setempat.

Salah satu contoh LPD adalah LPD Desa Pakraman Lalanglinggah.Awalnya LPD ini merupakan suatu lembaga keuangan KISMAR (Kumpulan Insan Marhaenis) tahun 1999. Kemudian pada Oktober 2002 memperoleh status hukum dan berubah nama menjadi Lembaga Perkreditan Desa (LPD) Desa Pakraman Lalanglinggah. Sejak berdiri hingga sekarang Lembaga Perkreditan Desa (LPD) Desa Pakraman Lalanglinggah setiap tahunnya mengalami perkembangan yang cukup baik.Tentunya semua keberhasilan yang diraih oleh Lembaga Perkreditan Desa (LPD) Desa Pakraman Lalanglinggah tidak luput dari peranan manajemen dalam pengelolaan ekuitas.

Istilah ekuitas sering digunakan sebagai padan kata darimodal, semenjak dikeluarkannya PSAK No. 1 (Revisi 2009) pada tanggal 15 Desember 2009 yang menyatakan bahwa istilah modal telah digantikan menjadi ekuitas.Pengertian ekuitas adalah hak residual atas aktiva perusahaan setelah dikurangi semua kewajiban. Ekuitas memiliki peranan sangat penting dalam Lembaga Perkreditan Desa (LPD), karena dengan adanya ekuitas, LPD mampu melaksanakan kegiatan operasionalnya. Riyanto (2001) menyatakan bahwa "Besarnya modal sangat mempengaruhi kemampuan perusahaan untuk membiayai seluruh aktifitas bisnis perusahaan".

Lembaga keuangan khususnya LPD membutuhkan dana untuk menunjang kegiatan usahanya, dalam hal ini artian dana adalah ekuitas kerja. Adanya ekuitas kerja yang cukup sangat penting bagi Lembaga keuangan khususnya bagi LPD untuk beroperasi seekonomis mungkin dan tidak mengalami kesulitan keuangan, sehingga konsentrasi dapat dititik beratkan pada pencapaian hasil yang lebih tinggi lagi.

LPD dalam usahanya tentu memiliki tujuan untuk memperoleh laba yang maksimal serta mampu mempertahankan kontinuitas usahanya.Agar hal tersebut dapat tercapai, maka diperlukanlah manajemen ekuitas kerja yang baik. Hanafi, (2005:125) menyatakan bahwa : "Manajemen atau pengelolaan modal kerja merupakan hal yang sangat penting agar kelangsungan usaha sebuah perusahaan dapat dipertahankan". Kesalahan atau kekeliruan dalam pengelolaan ekuitas kerja akan mengakibatkan buruknya kondisi keuangan perusahaan sehingga kegiatan perusahaan dapat terhambat atau bahkan terhenti. Kelebihan ataupun kekeurangan ekuitas kerja, keduanya merupakan kondisi yang tidak menguntungkan.

Melihat terjadinya penurunan yang cukup signifikan pada prosentase perkembangan ekuitas yang dialami oleh LPD Desa Pakraman Lalanglinggah yakni sebesar $17,76 \%$ pada tahun 2013 menjadi $9,35 \%$ pada tahun 2014, maka dirasa perlu untuk menilai efisiensi penggunaan ekuitas oleh LPD tersebut, dimana efisiensi suatu Lembaga Perkerditan Desa (LPD) dapat dinilai dari rentabilitasnya yakni kemampuan untuk menghasilkan laba dari ekuitas yang dimiliki, semakin tinggi laba yang diperoleh dengan modal kecil maka Lembaga Perkreditan Desa (LPD) dikatakan semakin efisien. 
Pemilihan Lembaga Perkreditan Desa (LPD) Desa Pakraman Lalanglinggah sebagai subyek penelitian karena LPD ini tidak hanya berfokus pada kegiatan pokok LPD saja, namun juga telah melebarkan sayapnya dalam bidang jasa seperti pelayanan pembayaran Pajak Bumi dan Bangunan (PBB), pembayaran rekening listrik, dan pembayaran pajak kendaraan bermotor (samsat) serta untuk perjuli 2016 rencananya akan menerapkan layanan pembayaran BPJS. Hal ini tentu akan menambah pendapatan bagi LPD dan juga akan mempermudah masyarakat dalam pembayaran Pajak khususnya PBB dan pajak bermotor.

Berdasarkan hal tersebut maka penulis berkeinginan untuk menilai efisiensi penggunaan ekuitas pada Lembaga Perkreditan Desa, yang dituangkan dalam Tugas Akhir yang berjudul "Efisiensi Penggunaan Ekuitas Pada Lembaga Perkreditan Desa (LPD) Desa Pakraman Lalanglinggah Kabupaten Tabanan Periode 2013-2015.

\section{Metode Penelitian}

Penelitian ini dilakukan untuk memperoleh gambaran tentang efisiensi penggunaan ekuitas pada Lembaga Perkreditan Desa (LPD) Desa Pakraman Lalanglinggah Kabupaten Tabanan Periode 2013-2015. Adapun sistematika penelitian yang dilakukan pertama adalah dengan menentukkan lokasi penelitian yaitu Lembaga Perkreditan Desa (LPD) Desa Pakraman Lalanglinggah Kabupaten Tabanan, setelah menentukan lokasi dilanjutkan dengan merumuskan pokok permasalahan yang akan diteliti. Kemudian diperlukan kajian teori yang melandasi penelitian ini agar dapat menjawab permasalahan tersebut.

Setelah itu untuk memperoleh data yang diperlukan maka dilakukan pengumpulan data dengan berbagai sumber data dan metode pengumpulan data.Pengumpulan data dilakukan dengan metode dokumentasi, sedangkan untuk sumber data dikumpulkan dari data sekunder. Setelah pengumpulan data, akan dilakukan analisis data dengan menggunakan teknik pengolahan data deskriptif kuantitatif dimana didalamnya memberikan penjelasan mengenai angka-angka yang dapat dihitung yang dilakukan untuk memperoleh data dan informasi mengenai efisiensi penggunaan ekuitas pada Lembaga Perkreditan Desa (LPD) Desa Pakraman Lalanglinggah Kabupaten Tabanan, yang kemudian akan menghasilkan hasil penelitian dan dari hasil tersebut dapat ditarik suatu kesimpulan.

Subyek yang diteliti adalah LPD Desa Pakraman Lalanglinggah, sedangkan obyek penelitian adalah efisiensi penggunaan ekuitas periode 2013-2015.Jenis data yang digunakan adalah data kuantitatifdan data kualitatif.

Teknik pengumpulan data serta bahan-bahan yang diperlukan dalam penelitian inididapat melalui penelitian kepustakaan (library research) dan studi lapangan (field research)dengan metode dokumentasi. Dokumentasi adalah mencari dan mengumpulkan data mengenai hal-hal yang berupa laporan keuangan seperti laporan laba rugi dan neraca tahun 2013-2015, jumlah anggota, struktur organisasi beserta tugas dan wewenang, dan sejarah perusahaan.

Teknik analisis data yang digunakan adalah teknik analisis deskriptif kuantitatif.Teknik analisis deskriptif kuantitatif digunakan untuk menggambarkan, memberikan penjelasan atau keterangan sesuai dengan data yang diperoleh berupa angka yang dapat dihitung untuk memperoleh data dan informasi dalam hal ini mengenai efisiensi penggunaan ekuitas pada Lembaga Perkreditan Desa (LPD) Desa Pakraman Lalanglinggah Kabupaten Tabanan.

\section{Hasil Dan Pembahasan}

Penelitian ini dilakukan dengan menggunakan perhitungan rentabilitas ekonomis dan rentabilitas modal sendiri.Langkah awal dalam pengolahan data adalah dengan menghitung rentabilitas dan kemudian mengukur efisiensi ekuitasnya.

Berdasarkan data yang diperoleh dari LPD dapat diketahui pada tahun 2013 laba usaha sebesa Rp. 63.805.559, ekuitas Rp.409.284.133. dan tahun 2014 laba usaha sebesar Rp. 85.519.758, ekuitas sebesar Rp.447.567.692 serta tahun 2015 laba usaha sebesar Rp 78.166.840, ekuitas sebesar Rp. 498.879.450.

Berdasarkan data tersebut maka rentabilitas ekonimis dapat dihitung, dimana rentabilitas ekonomis dapat dihitung dari membandingkan laba usaha dengan 
ekuitas/cadangan. Sehingga dari perhitunga tersebut maka dapat diketahui rentabilitas ekonomi dari tahun 2013-2015 secara berturut-turut adalah sebagai berikut 0,1559 (15,59\%); $0,1911(19,11 \%)$; dan $0,1567(15,67 \%)$. Total rasio rentabilitasnya adalah 0,5037 dengan rata-rata $(\bar{X})$ rasio rentabilitas ekonomis $0,1679(16,79 \%)$. Hasil perhitungan rentabilitas ekonomis tersebut menunjukkan bahwa laba usaha pada tahun 2013 dicapai sebesar $15,59 \%$ dari jumlah ekuitas/cadangan. Pada tahun 2014 menunjukkan bahwa laba usaha dicapai sebesar 19,11\% dari jumlah ekuitas/cadangan serta pada tahun 2015 menunjukkan bahwa laba usaha dicapai sebesar $15,67 \%$ dari jumlah ekuitas/cadangan.

Dari data tersebut dapat diketahui bahwa rentabilitas ekonomis tahun 2013-2015 mengalami fluktuatif, dimana tahun 2013-2014 mengalami peningkatan sebesar 0,0352 dari 0,1559 menjadi 0,1911. Sedangkan untuk tahun 2014-2015 terjadi penurunan sebesar 0,0344 dari 0,1911 menjadi 0,1567.

Efisiensi dapat diukur dengan menggunakan rasio rentabilitas. Rasio rentabilitas merupakan kemampuan suatu perusahaan dalam menghasilkan laba pada periode tertentu.Setelah menghitung rentabilitas selanjutnya menghitung standar deviasi dimana standar deviasi dihitung dengan rumus $S=\sqrt{\frac{\sum\left(X_{i}-j X^{2}\right.}{n-1}}$ dimana $X_{i}$ adalah rasio rentabilitas setiap tahun, $X$ adalah rata-rata rentabilitas dan $n$ adalan jumlah tahun. Setelah melakukan perhitungan maka diperoleh standar deviasi (S) dari tahun 2013-2015 secara berturut-turut adalah sebagai berikut 0,$0085 ; 0,0164$; dan 0,0079.

Penggunaan ekuitas pada LPD Desa Pakraman Lalanglinggah tahun 2013 tergolong kurang efisien karena rasio rentabilitas ekonomis berada di bawah $(\bar{X} \pm S)$, yakni dengan nilai rentabilitas ekonomisnya $0,1559(15,59 \%)$. Nilai dari rentabilitasnya menunjukkan tingkat efisiensi dari penggunaan ekuitasnya, tahun 2013 menunjukkan tingkat efisiensinya sebesar $15,59 \%$ dari penggunaan ekuitas/cadangan. Nilai dari $(\bar{X}+\mathrm{S})$ adalah sebesar 0,1764 dan nilai $(\bar{X}-S)$ sebesar 0,1594 yang menunjukkan rentang nilainnya, karena nilai rentabilitas dibawah dari rentang nilai maka dikatakan kurang efisien.

Tahun 2014 tergolong sangat efisien karena rasio rentabilitas ekonomis berada di atas $(\bar{X} \pm S)$, dengan nilai rentabilitas ekonomisnya sebesar 0,1911 (19,11\%). Nilai dari rentabilitas menunjukkan tingkat efisiensi dari penggunaan ekuitasnya, sehingga tahun 2014 menunjukkan bahwa tingkat efisiensinya sebesar $15,59 \%$ dari penggunaan ekuitas/cadangan. Nilai dari $(\bar{X}+S$ ) adalah sebesar 0,1843 dan nilai $(\bar{X}-\mathrm{S})$ sebesar 0,1515 yang menunjukkan rentang nilai, karena nilai rentabilitas di atas dari rentang nilai maka dikatakan sangat efisien.

Kemudian untuk tahun 2015 tergolong kurang efisien karena rasio rentabilitas ekonomis berada di bawah $(\bar{X} \pm S)$, dengan nilai rentabilitas ekonomisnya sebesar 0,1567 $(15,67 \%)$. Nilai dari rentabilitas menunjukkan tingkat efisiensi dari penggunaan ekuitasnya, sehingga pada tahun 2015 menunjukkan tingkat efisiensinya sebesar 15,67\% dari penggunaan ekuitas/cadangan. Nilai dari $(\bar{X}+\mathrm{S})$ adalah sebesar 0,1758 dan nilai $(\bar{X}-\mathrm{S})$ sebesar 0,1600 menunjukkan rentang nilainnya, karena nilai rentabilitas di bawah dari rentang nilai maka dikatakan kurang efisien.

Selanjutnya hasil perhitungan dengan menggunakan rentabilitas modal sendiri pada LPD Desa Pakraman Lalanglinggah Periode 2013-2015. Diketahui tahun 2013 laba setelah pajak sebesar Rp 63.805.559, laba setelah pajak tahun $2014 \mathrm{Rp} 85.519 .758$ dan laba setelah pajak tahun 2015 Rp. 78.166.840. untuk moda; sendiri dari tahun 2013-2015 sebesar Rp 130.598.000 Dimana rentabilitas modal sendiri dapat dihitung dengan cara membandingkan laba setelah pajak dengan modal sendiri. Perhitungan rentabilitas modal sendiri menunjukkan nilai dari tahun 2013-2015 secara berturut-turut adalah sebagai berikut $0,4886(48,86 \%) ; \quad 0,6548(65,48 \%) ; \quad 0,5985(59,85 \%)$. Nilai rata-rata $(\bar{X})$ rasio rentabilitas modal sendiri sebesar 0,5806 (58,06\%) dan dengan Jumlah ekuitas sendiri (ekuitas dasar) dari tahun ke tahun konstan. Dari hasil perhitungan rentabilitas modal sendiri menunjukkan bahwa laba setelah pajak pada tahun 2013 dicapai sebesar $48.86 \%$ dari jumlah ekuitas sendiri. Pada tahun 2014 menunjukkan bahwa laba setelah pajak dicapai sebesar $65,48 \%$ 
dari jumlah ekuitas sendiri. Sedangkan pada tahun 2015 menunjukkan bahwa laba setelah pajak dicapai sebesar $59,85 \%$ dari jumlah ekuitas sendiri.

Berdasarkan data tersebut dapat diketahui bahwa rentabilitas modal sendiri dari tahun 2013-2015 mengalami fluktuatif, dimana tahun 2013-2014 mengalami peningkatan sebesar 0,1662 dari tahun 2013 sebesar 0,4886 menjadi 0,6548 pada tahun 2014. Sedangkan untuk tahun 2014-2015 terjadi penurunan sebesar 0,0563 dari tahun 2014 sebesar 0,6548 menjadi 0,5985 pada tahun 2015.

Setelah menghitung rentabilitas modal sendiri maka langkah selanjutnya menghitung standar deviasi. Dari perhitungan dapat diketahui bahwa nilai dari standar deviasi (S) secara berturut-turut dari tahun 2013-2015 adalah sebesar 0,0651; 0,0525; dan 0,0126. Berdasarkan perhitungan yang dilakukan maka diketahui penggunaan ekuitas pada LPD Desa Pakraman Lalanglinggah tahun 2013 tergolong kurang efisien karena besarnya rasio rentabilitas modal sendiri berada dibawah $(\bar{X} \pm S)$, yakni dengan nilai rentabilitas modal sendirinya sebesar 0,4886 (48,86\%). Nilai dari rentabilitas menunjukkan tingkat efisiensi dari penggunaan ekuitasnya, sehingga nilairentabilitas pada tahun 2013 sebesar 48,86\% menunjukkan jumlah tingkat efisiensidaripenggunaanekuitas sendiri. Besarnya nilai dari $(\bar{X}$ + S) adalah 0,6457 serta nilai dari ( $\bar{X}-\mathrm{S}$ ) sebesar 0,5155 yang menunjukkan rentang nilainya, karena nilai rentabilitasnya dibawah dari rentang nilai maka penggunaan ekuitasnya dikatakan kurang efisien.

Selanjutnya pada tahun 2014 penggunaan ekuitasnya tergolong sangat efisien karena rasio rentabilitas modal sendiri berada di atas $(\bar{X} \pm S)$, yakni dengan nilai rentabilitas modal sendiri sebesar $0,6548(65,48 \%)$. Besarnya nilai rentabilitas menunjukkan tingkat efisiensi dari penggunaan ekuitasnya, sehingga untuk tahun 2014 menunjukkan tingkat efisiensi dari penggunaan ekuitas sendiri adalah sebesar. $65,48 \%$. Nilai untuk $(\bar{X}+\mathrm{S})$ adalah sebesar 0,6331 dan nilai dari $(\bar{X}-S)$ sebesar 0,5281 , dimana kedua nilai tersebut menunjukkan rentang nilainnya. Sehingga penggunaan ekuitas pada tahun 2014 dikatakan sangat efisien kerana rentabilitasnya berada diatas rentang nilai.

Kemudian selanjutnya untuk tahun 2015 penggunaan ekuitas tergolong sangat efisien karena rasio rentabilitas modal sendiri berada diatas nilai $(\bar{X} \pm S)$, yakni dengan nilai rentabilitas modal sendiri sebesar $0,5985(59,85 \%)$ nilai dari rentabilitasnya menunjukkan tingkat efisiensi dari penggunaan ekuitasnya, maka untuk tahun 2015 menunjukkan tingkat efisiensi sebesar $59,85 \%$ dari penggunaaan ekuitas sendiri. Nilai dari $(\bar{X}+$ S) adalah sebesar 0,5932 dan untuk nilai $(\bar{X}-\mathrm{S}$ ) sebesar 0,5680 yang keduanya menunjukkan rentang nilai, karena nilai rentabilitas di atas dari rentang nilai maka efisiensi penggunaan ekuitas dikatakan sangat efisien.

Berdasarkan hasil perhitungan dari rasio rentabilitas ekonomis maka diperoleh hasil bahwa penggunaan ekuitas pada LPD Desa Pakraman Lalanglinggah periode 2013 dan 2015 tergolong kurang efisien karena rasio rentabilitas ekonomis berada di bawah $(\bar{X} \pm S)$, dan untuk tahun 2014 tergolong sangat efisien karena rasio rentabilitas ekonomis berada di atas $(\bar{X} \pm S)$. Sedangkan untuk perhitungan rasio rentabilitas modal sendiri diperoleh hasil bahwa penggunaan ekuitas pada LPD Desa Pakraman Lalanglinggah untuk tahun 2013 tergolong kurang efisien karena rasio rentabilitas berada di bawah $(\bar{X} \pm S)$, dan untuk periode 2014 dan 2015 tergolong sangat efisien karena rasio rentabilitas berada di atas ( $\bar{X} \pm S$ ).

Hasil penelitian ini mendukung mendukung teori dari Munawir (2004) yang menyatakan rentabilitas yang tinggi lebih penting dari keuntungan yang besar, karena keuntungan tersebut tidak menjamin perusahaan rendabel. HasiL penelitian ini juga mendukung hasil penelitian dari Wati (2012) menyatakan bahwa semakin tinggi laba yang diperoleh dengan modal kecil maka LPD dikatakan semakin efisien. Besar kecilnya laba yang diperoleh suatu LPD tergantung pada kemampuan pengurus LPD dalam pengelolaan asetnya.

Dalam penggunaan kedua rumus dari rentabilitas yaitu rentabilitas ekonomis dan rentabilitas modal sendiri didapatkan hasil yang berbeda. Tahun 2013 rasio rentabilitas ekonomis sebesar 0,1559 atau menunjukan 15,59\% penggunaan ekuitas pada LPD Desa 
Pakraman Lalanglinggah yang tergolong kurang efisien. Tahun 2014 rasio rentabilitas ekonomis sebesar 0,1911 atau menunjukan 19,11\% penggunaan ekuitas pada LPD Desa Pakraman Lalanglinggah yang tergolong sangat efisien. Dan untuk Tahun 2015 rasio rentabilitas ekonomis sebesar 0,1567 atau menunjukan 15,67 \% penggunaan ekuitas pada LPD Desa Pakraman Lalanglinggah yang tergolong kurang efisien.

Sedangkan untuk rentabilitas modal sendiri, pada tahun 2013 menunjukkan rasio rentabilitas modal sendiri sebesar 0,4886 atau $48,86 \%$ penggunaan ekuitas pada LPD Desa Pakraman Lalanglinggah dan tergolong kurang efisien. Tahun 2014 menunjukkan rasio rentabilitas modal sendiri sebesar 0,6548 atau $65,48 \%$ penggunaan ekuitas pada LPD Desa Pakraman Lalanglinggah dan tergolong sangat efisien. Serta tahun 2015 menunjukkan rasio rentabilitas modal sendiri sebesar 0,5985 atau $59,85 \%$ penggunaan ekuitas pada LPD Desa Pakraman Lalanglinggah dan tergolong sangat efisien.

Penggunaan rasio rentabilitas ekonomis membuktikan bahwa penggunaaan ekuitas dari tahun 2013-2015 terjadi fluktuatif, dimana tahun 2013 dan 2015 penggunaan ekuitas kurang efisien dan untuk tahun 2014 penggunaan ekuitas sangat efisien. Sedangkan untuk penggunaan rasio rentabilitas modal sendiri menunjukkan pada tahun 2013 penggunaan ekuitas pada LPD Desa Pakraman Lalanglinggah tergolong kurang efisien, dan untuk tahun 2014-2015 penggunaan ekuitas pada LPD Desa Pakraman Lalanglinggah tergolong sangat efisien.

Dari perhitungan menggunakan rasio rentabilitas modal sendiri menunjukkan adanya perkembangan dalam pengelolaan ekuitas yang baik.Tiga tahun kebelakang yang telah diteliti yakni dari tahun 2013-2015 menunjukkan hasil yang baik pada tahun 2014-2015. Walaupun pada tahun 2015 mengalami penurunan nilai rentabilitas, namun tahun 2015 masih menunjukan penggunaan ekuitas yang tergolong sangat efisien. Penurunan nilai rentabilitas pada tahun 2015 diakibatkan adanya gagal panen yang dialami oleh petani di lingkungan Desa Pakraman Lalanglinggah sehingga mempengaruhi pendapatan LPD karena kemampuan anggota dalam menyimpan uang maupun pembayaran kredit menjadi berkurang.

Dengan melihat hasil penelitian dapat diketahui untuk tahun 2013 pada rentabilitas ekonomis penyebab dari ketidakefisienan penggunaan ekuitas karena adanya kegiatan upacara agama (Karya Agung Ngenteg LInggih dan Mupuk Pedagingan) di Desa Pakraman Lalanglinggah, sehingga mengakibatkan kinerja karyawan menjadi kurang optimal dan sebagian dari dana LPD disumbanggkan dalam upacara agama tersebut. Tahun 2014 pada rentabilitas ekonomis penyebab efisiensi penggunaan ekuitas karena ekuitas kerja yang dimiliki dikelola dengan cukup baik.Ini dibuktikan dengan nilai rentabilitas yang dihasilkan cukup tinggi. Serta untuk tahun 2015 penyebab ketidakefisienan pada rentabilitas ekonomis disebabkan adanya gagal panen yang dialami oleh petani di lingkungan Desa Pakraman Lalanglinggah sehingga mempengaruhi pendapatan LPD karena kemampuan anggota dalam menyimpan uang maupun pembayaran kredit menjadi berkurang.

Tahun 2013 pada rentabilitas modal sendiri mengalami ketidakefisienan disebabkan adanya kegiatan upacara agama (Karya Agung Ngenteg LInggih dan Mupuk Pedagingan) di Desa Pakraman Lalanglinggah, sehingga mengakibatkan kinerja karyawan menjadi kurang optimal dan sebagian dari dana LPD disumbanggkan dalam upacara agama tersebut. Tahun 2014 dengan perhitungan rentabilitas modal sendiri, penyebab dari efisiensi penggunaan ekuitas karena ekuitas kerja yang dimiliki dapat dikelola dengan baik itu dapat dilihat dari hasil rentabilitas modal sendiri yang tinggi. Serta pada tahun 2015 dengan perhitungan rentabilitas modal sendiri masih tergolong efisien namun rentabilitasnya mengalami penurunan yang diakibatkan adanya gagal panen yang dialami oleh petani di lingkungan Desa Pakraman Lalanglinggah sehingga mempengaruhi pendapatan LPD karena kemampuan anggota dalam menyimpan uang maupun pembayaran kredit menjadi berkurang. 


\section{Simpulan dan Saran}

Berdasarkan hasil penelitian dan pembahasan mengenai efisiensi penggunaan ekuitas pada Lembaga Perkreditan Desa (LPD) Desa Pakraman Lalanglinggah Kabupaten Tabanan periode 2013-2015 yang telah diuraikan diatas, maka dapat disimpulkan bahwa

Penggunaan ekuitas pada LPD desa Pakraman Lalanglinggah dapat dilihat dengan menggunakan rentabilitas ekonomis dan rentabilitas modal sendiri. Bila dilihat dari rentabilitas ekonomis maka penggunaan ekuitas pada tahun 2013-2015 mengalami fluktuatif, yakni pada tahun 2013 penggunaan ekuitas dikatakan kurang efisien disebabkan adanya kegiatan upacara agama (Karya Agung Ngenteg LInggih dan Mupuk Pedagingan) di Desa Pakraman Lalanglinggah, sehingga mengakibatkan kinerja karyawan menjadi kurang optimal dan sebagian dari dana LPD disumbanggkan dalam upacara agama tersebut. Tahun 2014 penyebab efisiensi penggunaan ekuitas karena ekuitas kerja yang dimiliki dikelola dengan cukup baik.Ini dibuktikan dengan nilai rentabilitas yang dihasilkan cukup tinggi. Serta untuk tahun 2015 penyebab ketidakefisienan karena adanya gagal panen yang dialami oleh petani di lingkungan Desa Pakraman Lalanglinggah sehingga mempengaruhi pendapatan LPD karena kemampuan anggota dalam menyimpan

uang maupun pembayaran kredit menjadi berkurang.

Kemudian bila dilihat dari rentabilitas modal sendiri penggunaan ekuitas pada tahun 2013 tergolong kurang efisien dan pada tahun 2014-2015 tergolong sangat efisien. Ketidakefisienan yang terjadi pada tahun 2013 dikarenakan adanya kegiatan upacara agama (Karya Agung Ngenteg LInggih dan Mupuk Pedagingan) di Desa Pakraman Lalanglinggah, sehingga mengakibatkan kinerja karyawan menjadi kurang optimal dan sebagian dari dana LPD disumbanggkan dalam upacara agama tersebut. Pada tahun 2014 efisiensi penggunaan ekuitas karena ekuitas kerja yang dimiliki dapat dikelola dengan baik itu dapat dilihat dari hasil rentabilitas modal sendiri yang tinggi. Serta pada tahun 2015 masih tergolong efisien namun rentabilitasnya mengalami penurunan yang diakibatkan adanya gagal panen yang dialami oleh petani di lingkungan Desa Pakraman Lalanglinggah sehingga mempengaruhi pendapatan LPD karena kemampuan anggota dalam menyimpan uang maupun pembayaran kredit menjadi berkurang.

Saran yang dapat disampaikan atas hasil penelitian yang dilakukan pada Lembaga Perkreditan desa (LPD) Desa Pakraman Lalanglinggah yaitu kepada pihak Lembaga Perkreditan desa (LPD) Desa Pakraman Lalanglinggah yakni diharapkan untuk tahun-tahun berikutnya agar pengelolaan ekuitas kerja pada Lembaga Perkreditan Desa (LPD) Desa Pakraman Lalanglinggah lebih ditingkatkan lagi sehingga tidak adanya dana yang menganggur atau dana yang tidak produktif atapun tidak terjadi kekurangan dana yang dapat menyebabkan kegagalan pada LPD. Diharapkan Pengurus LPD mampu memanajen ekuitas kerjanya dengan lebih baik lagi sehingga tidak terjadi ketidakefisiensian dalam penggunaan ekuitas, karena hal ini akan berpengaruh dalam pemasaran LPD yakni dapat mengurangi tingkat kepercayaan masyarakat dalam menyimpan maupun meminjam uang pada LPD tersebut. Sebaiknya terus meningkatkan pendapatan agar dana perusahaan terus meningkat dengan cara memanfaatkan seoptimal mungkin ekuitas kerja yang ada. Rasio rentabilitas yang rendah sebaiknya diantisipasi dengan mengurangi biaya operasional yang kurang perlu serta LPD Desa Pakraman Lalanglinggah perlu lebih memperhatikan kebijaksanaan dalam manajemen ekuitas kerja yaitu dalam penentuan besarnya dana yang diinvestasikan dalam unsur-unsur ekuitas kerja sesuai dengan kebutuhan usaha, sehingga dapat memaksimalkan laba

\section{DAFTAR PUSTAKA}

2002. Peraturan Daerah Provinsi Bali Nomor 8 Tahun 2002 Tentang Lembaga Perkreditan Desa disertai Keputusan Gubernur.

2003. Peraturan Daerah Provinsi Bali Nomor 3 Tahun 2003 Tentang Lembaga Perkreditan Desa disertai Keputusan Gubernur.

2012. Peraturan Daerah Provinsi Bali Nomor 4 Tahun 2012 Tentang Lembaga Perkreditan Desa disertai Keputusan Gubernur. 
Algifari. 1997. Statistika Ekonomi 1. Edisi Kedua. STIE YKPN Yogyakarta.

Alma, Buchari. 2003. Pengantar Bisnis. Edisi Kedelapan. Bandung: Alfabeta.

Budi, Nanang. 2013. Pengertian dan Jenis-Jenis Rentabilitas. Tersedia pada http://nanangbudianas.blogspot.co.id/2013/02/pengertian-dan-jenis-jenisrentabilitas 5.html (12 Maret 2016 )

Cintya, Laksmi. 2014. Sejarah Dan Pengertian Lembaga Perkreditan Desapada https://www.scribd.com/doc/213344381/Sejarah-Dan-Pengertian-LembagaPerkreditan-Desa (7 Maret 2016)

Hatake, hery. 2014. Ulasan Tentang Lembaga Perkreditan Desa (LPD) di Provinsi Bali: Sebuah Lembaga Keuangan Mikro yang Dibangun dari Kebudayaan Daerah dan Telah Berhasil Membangun Perekonomian dan Kebudayaan DaerahPada http://dokumen.tips/documents/ulasan-tentang-Ipd-di-bali.html (7 Maret 2016)

Hermawati, Sri.2014. Efisiensi Penggunaan Modal Pada Lembaga Perkreditan Desa (LPD) Desa pakraman Banyuning Kabupaten Buleleng Periode 2011-2013. Tugas akhir Singaraja.

Jumingan. 2008. Analisis Laporan Keungan. Jakarta: PT. Bumi Aksara.

Jusup, Ai Haryono. 2005. Dasar - dasar Akuntansi Jilid 1. Edisi keenan. STIE YKPN. Yogyakarta:

Jusup, Ai Haryono. 2005. Dasar - dasar Akuntansi Jilid 2. Edisi keenan. STIE YKPN Yogyakarta.

Kasmir, Dr. 2015. Analisis Laporan Keuangan. Edisi Revisi. PT. Rajagrafindo Persada Jakarta.

Kusuma, Afandi. 2012. Rentabilitas laba dengan aktiva / modal yang menghasilkan laba. Tersedia pada http://www.bukupr.com/2012/03/rentabilitas-laba-dengan-aktivamodal.html (13 Maret 2016

Mardiasmo. 2009. Akuntansi Sektor Publik. Andi Yogyakarta.

Meta.2009. Definisi/Pengertian Efisiensi. Tersedia pada https://dansite.wordpress.com/2009/03/28/pengertian-efisiensi/ (11 Maret 2106)

Pemerintah Daerah Provinsi Bali. 1998. Peraturan Daerah Provinsi Bali Nomor 2 Tahun 1998 Tentang Lembaga Perkreditan Desa.

Pipih,Teh. 2009. Rentabilitas Ekonomi (Earning Power). Tersedia pada http://pipihhopipah.blogspot.co.id/2009/10/rentabilitas-ekonomi-earning-power.html (13 Maret 2016)

Sari, Arinda.2012. Manajemen Keuangan dan Permodalan Koperasi. Tersedia pada http://arindasari915.blogspot.com/2012/12/manajemen-keuangan-danpermodalan.html (19 april 2014).

Sofyan Syafri Harahap. 2004. Analisis Kritis Atas Laporan Keuangan. Jakarta : PT Raja Grafindo Persada

Suartana, I Wayan. 2009. Aristektur Pengelolaan Risiko Pada Lembaga Perkreditan Desa (LPD). Udayana University Press: Bali.

Subekti. 2011. Analisis Tingkat Efisiensi Penggunaan Modal Kerja dan Prediksi Efisiensi Lanjutan Penggunaan Modal Kerja. Tegal: Skripsi

Sugiyono. 2011. Metode Penelitian Kuantitatif Kualitatif Dan R \& D. Bandung: Alfabeta.

Sulindawati, Erni. 2011. Buku Ajar Manajemen Keuangan. Singaraja: Percetakan Ganesha.

Tim pedoman akuntansi bank perkreditan rakyat. 2010. Pedoman Akuntansi Bank Perkreditan Rakyat. Jakarta: diterbitkan atas kerjasama IAI. 
VOL.6, NO. 2, OKTOBER 2017

p-ISSN : 2337-537X

Wardika, I Nyoman. 2006. Analisis Efisiensi Penggunaan Modal pada LPD Desa Pakraman Lembeng di Gianyar. r: Skripsi. Denpasar

Wikipedia.

2015.

Simpangan

baku.

Tersediapadahttps://id.wikipedia.org/wiki/Simpangan baku\#Simpangan Baku Samp el (12 Maret 2016)

Wirawan, Nata.2001. Statistik I, Edisi Kedua. Denpasar: Keraras Emas. 